\title{
Selection and Evaluation of High Yielding Horn- type Plantain Clones in Puerto Rico: An Explanation for Their Behavior ${ }^{1,2}$
}

\author{
Héber Irizarry, José Rodriguez-García and Nicolás Diaz ${ }^{3}$
}

\begin{abstract}
Fifty-seven clonal selections of the horn-type Maricongo cultivar were evaluated at six locations. Five of these selections averaged 44 marketable fruits and $13.1 \mathrm{~kg} / \mathrm{bunch}$. Although asexually propagated, variability within the clonal population was quite high for all the bunch and plant characteristics studied. Reversion from the horn to the French type occurred in some plants and others produced horn-type bunches with fewer than $\mathbf{3 0}$ large fruits. Both of these "off-type" plantains appeared randomly in the clonal populations at all locations. These "off-type" plants produced "true to type" offspring in subsequent $\mathrm{Pn}$ generations. An explanation of the possible mechanism responsible for this occurrence is discussed. Irrespective of clone, all plant and bunch characteristics were affected by location. Considering the variability observed within the clonal population as well as effects of the environment, it is estimated that $85 \%$ of the suckers originating from a Maricongo stump with a yield potential of 50 or more marketable fruits/bunch will produce bunches containing $\mathbf{4 0}$ or more fruits in the plant crop. If the $15 \%$ of the "off-type" plants are allowed to continue mingling within the population, they will multiply "true-to-type," and after Pn generations will constitute a majority in a clonal selection that once had a high yield potential.
\end{abstract}

\section{INTRODUCTION}

Local plantain (Musa acuminata $\times$ M. balbisiana, AAB) production is about 330 million fruits/year with a farm value of $\$ 32$ million. About $90 \%$ is obtained from the tall Maricongo cultivar, and the remainder from the Common Dwarf plantain. Both of these cultivars are of the horn-type i.e., male flowers disappear from the bunch raquis after flowering and production fruits of good size and quality.

In commercial plantings, farmers usually obtain low yields, from 50,000 to 70,000 marketable fruits/ha, with about 2,500 plants/ha and deficient management. In such fields, plants bearing less than 30 fruits and others yielding over 60 fruits/bunch are found as well as a few plants which have reverted to the French-type, i.e., persistence of male flowers on the bunch rachis after flowering. Except for their bunch characteristics, there is no morphological trait available which can be used to recognize high and low yielding plants in a mixed population.

${ }^{1}$ Manuscript submitted to Editorial Board September 10, 1984.

${ }^{2}$ This paper covers work carried out cooperatively between the Agricultural Research Service, USDA, and the Agricultural Experiment Station, University of P.R., Rio Piedras, P.R.

${ }^{3}$ Research Horticulturist, Agricultural Research Service, USDA; Associate Agronomist, Agricultural Experiment Station, University of P.R.; and Research Technician, Agricultural Research Service, USDA, Rio Piedras, P.R., respectively. 
Perhaps part of the variability observed among individuals of the same cultivar, can be explained by the histological origin of the propagating material and the possible development of chimeras. According to Esau (5), adventitious buds in monocotyledon plants always arise with no vascular connection to the apical meristem. Furthermore, Barker and Steward (1) reported that in edible bananas (Musa acuminata, AAA) all commercial propagating material is considered to originate from lateral or adventitious buds. This condition, along with the continuous propagation of the crop by vegetative means, drastic changes in the immediate environment and the high level of heterozygosity and high degree of ploidy, make plantains a crop highly susceptible to somatic changes. Indeed, this is the only source of genetic variability available in the crop unless new breeding techniques are developed. Varietal improvement through selection of desirable sport mutations has been accomplished in many fruits crops $(4,11)$.

Cheesman (2), Gross and Simmonds (6), and Richardson (10) reported spontaneous mutation in bananas based on observed morphological changes in the plant and the proven attachment between the parent and the mutant sucker growing side by side from the same stool. These reports do not indicate changes in the bunch or individual fruit characteristics nor do they concern plantains.

The purpose of this study was to select apparently superior plantain clones from commercial plantings and test them under different ecological conditions.

\section{MATERIALS AND METHODS}

Fifty-seven clones of horn-type plantains were selected from apparently virus-free plants bearing bunches with over 50 marketable fruits and weighing at least $18.2 \mathrm{~kg}$ in plantations from Puerto Rico and the Dominican Republic. They were multiplied and tested in 6 ecological regions of Puerto Rico over a period of 6 years from February 1975 to June 1981.

Following is a brief description of the experimental sites which had similar average minimum and maximum annual temperatures of about 18.5 and $30.5^{\circ} \mathrm{C}$, respectively, with a mean monthly variation of about $0.5^{\circ} \mathrm{C}$.

Aguas Buenas. The experiment was planted on a private farm at about $400 \mathrm{~m}$ elevation. Annual rainfall is about $1,800 \mathrm{~mm}$. The soil is Humatas clay (Typic Tropohumults), a deep well-drained, strongly acid soil formed from residual material weathered from volcanic rocks. The soil had a $\mathrm{pH}$ of 5.2 and contained $9.7 \mathrm{p} / \mathrm{m}$ of "available" P (Bray method) and 1.0, 2.2 and 6.5 meq of exchangeable $\mathrm{K}, \mathrm{Mg}$ and $\mathrm{Ca}$, respectively/100 $\mathrm{g}$ of soil.

Cidra. The experiment was located on Highway 172, at an elevation of 
about $450 \mathrm{~m}$. Mean annual rainfall is about $1,900 \mathrm{~mm}$. The soil is Torres clay (Plinthic Palehumults). The soil had a $\mathrm{pH}$ of 4.5 and contained 11.7 p/m of "available" P; .3 meq of exchangeable K, 2.0 meq of exchangeable $\mathrm{Mg}$ and $2.6 \mathrm{meq}$ of exchangeable $\mathrm{Ca} / 100 \mathrm{~g}$ of soil. Exchangeable and easily reducible $\mathrm{Mn}$ was 100 and $500 \mathrm{p} / \mathrm{m}$, respectively.

Corozal. The experiment was established at the Corozal Substation, about $200 \mathrm{~m}$ above sea level. Annual rainfall is about $1,700 \mathrm{~mm}$. The soil is Corozal clay (Aquic Tropudults) derived from residual volcanic rocks. The soil had a pH of 5.2 contained $12.1 \mathrm{p} / \mathrm{m}$ of "available" $\mathrm{P}$; and 0.3 , 2.9 and 8.9 meq of exchangeable $\mathrm{K}, \mathrm{Mg}$ and $\mathrm{Ca}$, respectively/100 $\mathrm{g}$ of soil.

Gurabo. The experiment was established at the Gurabo Substation at an elevation of only $80 \mathrm{~m}$. Mean annual rainfall is about 1,500 $\mathrm{mm}$. The soil is Coloso clay (Aeric Tropic Fluvaquents) with restricted internal drainage. The soil was formed from alluvial material consisting of recent deposits of silt and clay. The soil had a pH of 6.4 and contained $4.4 \mathrm{p} / \mathrm{m}$ of "available" $\mathrm{P}$ and $0.4,15.7$ and 17.7 meq of exchangeable $\mathrm{K}, \mathrm{Ca}$ and $\mathrm{Mg}$, respectively/100 $\mathrm{g}$ of soil.

Rocha. The experiment was located near Moca at an elevation of about $150 \mathrm{~m}$. Rainfall is about 2,200 $\mathrm{mm}$ per annum. The soil is Moca clay (Vertic Tropudults), formed from plastic clay, gravel and cobblestones. The soil had a $\mathrm{pH}$ of 4.8 and contained $9.7 \mathrm{p} / \mathrm{m}$ of "available" $\mathrm{P} ; 0.7 \mathrm{meq}$ of exchangeable $\mathrm{K} ; 5.5$ meq of exchangeable $\mathrm{Mg}$; and 15.3 meq of exchangeable $\mathrm{Ca} / 100 \mathrm{~g}$ of soil.

San Lorenzo. The experiment was established on a private farm at an elevation of about $200 \mathrm{~m}$. Mean annual rainfall is about 2,000 $\mathrm{mm}$. The soil is Cayagua sandy clay (Aeric Tropaqualfs) from residuum of coarse textured plutonic rocks, and has a moderately permeable surface layer but with restricted internal drainage. The soil had a $\mathrm{pH}$ of 5.6 and contained $6.3 \mathrm{p} / \mathrm{m}$ of availabe $\mathrm{P}$, and $0.2,3.1$ and 3.7 meq. of exchangeable $\mathrm{K}, \mathrm{Mg}$ and $\mathrm{Ca}$, respectively/100 $\mathrm{g}$ of soil.

At all locations the soil was plowed with a tractor except in Aguas Buenas where the soil was plowed with oxen and a hillside plow. When necessary, ground limestone was incorporated into a soil to raise the $\mathrm{pH}$ to about 5.5

Twenty-four corms from each clone were planted at each location in replicated plots. Plants were planted at $1.8 \times 1.8 \mathrm{~m}$ or $1.8 \times 1.5 \mathrm{~m}$, about 3,000 to 3,500 plants/ha. Soil insects and nematodes were controlled with either or alternate granular applications of Dasanit 15 G \{0,0-dietyl 0-[4(methylsulfinyl) phenyl] phosphorodithioate\}, Mocap $10 \mathrm{G}$ (0-ethyl S, sdipropyl phosphorodithioate), Furadan 10 G [DL 3-(-2-furfuryl)-4-hydroxy-2-methyl-2-cyclopenten-1-one ester of DL-cis-transmonocarboxylic acid] and Temik $10 \mathrm{G}$ [2-methyl-2-(methylthis) propionaldehyde 0- 
(methyl carbamoyl) oxime] at the rate of 28 to $56 \mathrm{~g} /$ plant at planting and 4 to 6 months later. Weeds were suppressed by post-emergence applications of Gramoxone (1:1 dimethyl-4, 4-bipyridinium dichloride) and Round-up [ $\mathrm{N}$-(phosphonomethyl) glycine] at the rate of 2.5 and 4.9 L/ha, respectively. Starting about 6 months after planting, the plants were sprayed with either Bravo-500 (tetrachloroisophtha-lonitrile) or mineral orchard oil at the rate of 4.9 and $9.4 \mathrm{~L} / \mathrm{ha}$, respectively, every 15 days to control the yellow Sigatoka disease caused by Mycosphaerella musicola.

All plants received a total of $3,300 \mathrm{~kg} / \mathrm{ha}$ of a $10-5-20-3\left(\mathrm{~N}, \mathrm{P}_{2} \mathrm{O}_{5} \mathrm{~K}_{2} \mathrm{O}\right.$ and $\mathrm{MgO}$ ) fertilizer containing $23 \mathrm{~kg} / \mathrm{T}$ of a fritted micronutrient mixture applied 2, 5, and 9 months after planting. During dry spells lasting more than 3 weeks supplemental irrigations was applied to the Gurabo and Corozal experiments at the rate of $40 \mathrm{~mm}$ biweekly.

Plant height and diameter of the pseudostem were determined at bunch

TABLE 1.-Bunch and plant characteristics of five high yielding plantain clones tested in six ecological regions of Puerto Rico. Apparent differences are not statistically significant

\begin{tabular}{ccccccc}
\hline & \multicolumn{3}{c}{ Bunch characteristics } & & \multicolumn{2}{c}{ Plant characteristics } \\
\cline { 2 - 3 } Clone & Fruits & Hands & Weight & & $\begin{array}{c}\text { Diameter } \\
\text { of pseudostem }\end{array}$ & $\begin{array}{c}\text { Plant } \\
\text { height }\end{array}$ \\
\hline & No. & No. & $\mathrm{kg}$ & $\mathrm{cm}$ & $\mathrm{m}$ \\
$\mathrm{A}$ & 45.0 & 6.9 & 13.6 & & 17.1 & 3.7 \\
B & 43.9 & 6.7 & 13.0 & & 17.5 & 3.7 \\
C & 43.5 & 6.8 & 13.1 & & 17.4 & 3.7 \\
D & 43.1 & 6.7 & 12.9 & & 17.1 & 3.8 \\
E & 42.6 & 6.7 & 13.0 & & 17.6 & 3.7 \\
\hline
\end{tabular}

emergence. Bunches were harvested about 3.5 months later, weighed and the number of hands and fruits determined.

The data were analyzed as randomized complete blocks in which locations were the blocks and clones the treatments. Locations and clones were compared with Duncan's multiple range test.

\section{RESULTS AND DISCUSSION}

A total of 57 plantain clones were propagated and tested. Thirty-one clones were planted at four locations, 14 at five locations, and 12 clones were tested at all six locations. In this study, only data from the 12 clones grown at all locations are considered.

Only the best clones were chosen following the subset selection procedure described by Chew (3). Five clones shared the best positions at all locations as to number of marketable fruits and weight/bunch (table 1). Differences among these five high yielding clones for the bunch and plant 
characteristics studied were negligible. On the average, these plants produced bunches weighing $13.1 \mathrm{~kg}$ with 6.8 hands and 44 fruits. Mean plant height and diameter of pseudostem were $3.7 \mathrm{~m}$ and $17.3 \mathrm{~cm}$, respectively.

These clones, denoted as A, B, C, D, and E, yielded above average for all clones at the six locations in terms of both number of marketable fruits and bunch weight, and either the same or above average at each location (fig. 1 and 2). The statistical values obtained from measurements

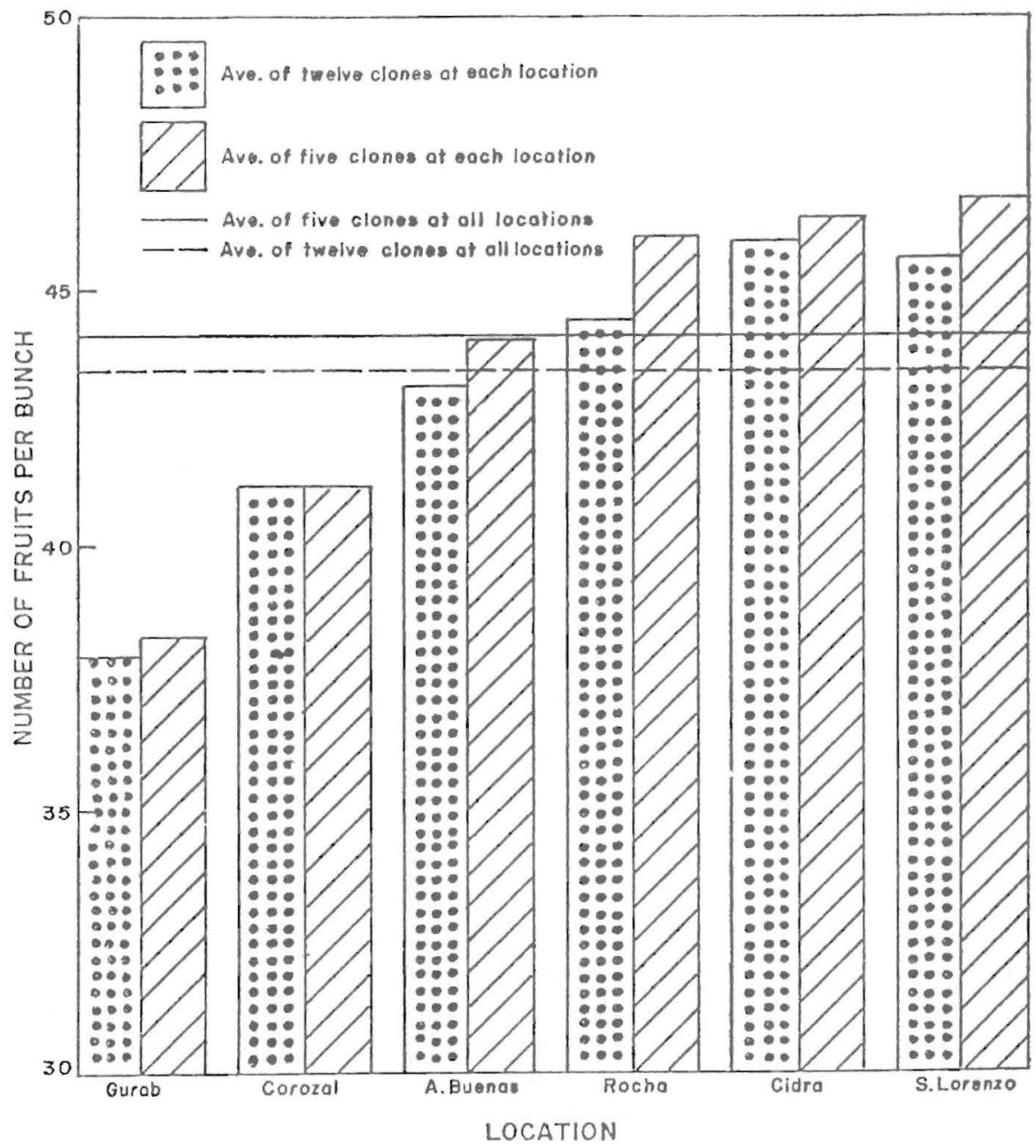

Fig. 1.-Mean number of marketable fruits/bunch harvested from five and twelve plantain clones grown at six locations in Puerto Rico. 


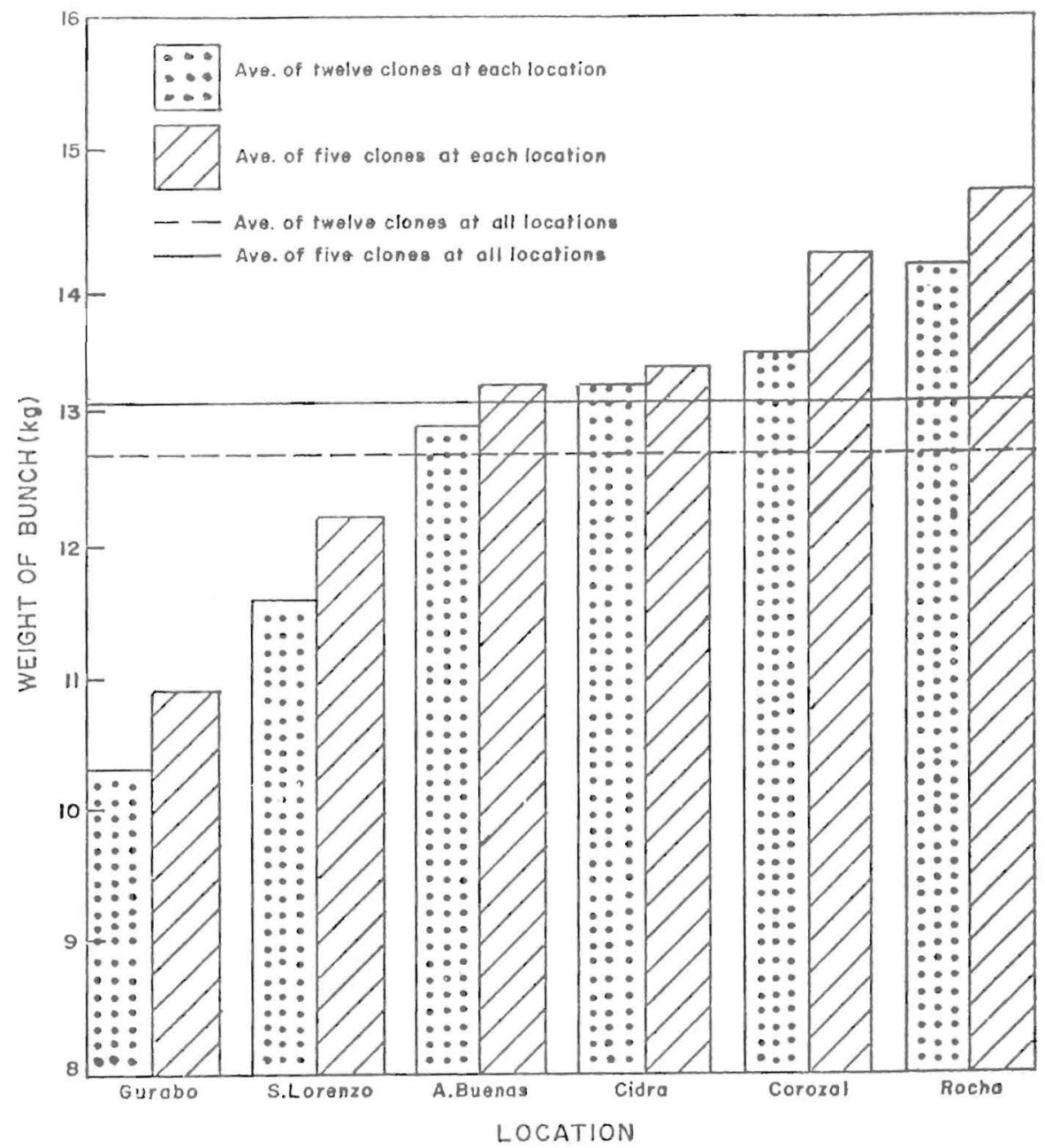

FIG. 2.-Mean weight of bunches obtained from five and twelve plantain clones grown at six locations in Puerto Rico.

of variability in bunch and plant characteristics of the five superior clones are shown in table 2. Variability within the clonal populations was quite high. Among yield components, number of hands and fruits/ bunch varied less than weight of bunches. Weight of the bunches ranged from 7.1 to $21.1 \mathrm{~kg}$, with an $\sigma$ value of 2.50 and a C.V. of $19.0 \%$. Number of hands/bunch varied from 3 to 8 hands, with an $\sigma$ value of 0.71 and C.V. of $10.6 \%$. Mean number of fruits/bunch ranged from a minimum of 24 to a maximum of 60 fruits, with an $\sigma$ value of 5.89 and a C.V. of $13.4 \%$. 
Out of a total of 613 bunches harvested from these five superior clones at the six locations, 15 plants produced bunches with less than 30 fruits, whereas only 8 plants yielded 60 fruits/bunch. These high yielding plants were produced from clones A, C and E at the Aguas Buenas, Cidra, San Lorenzo and Rocha experiments. Plants producing fewer than 5 hands and less than 30 fruits/bunch appeared randomly among the clones at all locations, but were more frequent in the Gurabo and Corozal experiments.

Twelve plants reverted from the horn to the French-type plantain. These plants appeared randomly in 9 different clones at all locations and produced bunches containing 64 to 106 relatively small fruits typical of the French type. Propagation and testing of some of these "off-types", i.e., plants producing horn-type bunches with fewer than 30 fruits or French-type bunches, revealed that they continued "true-to-type" in

TABLE 2.-Range, mean ( $\bar{x}$ ), standard deviation ( $\sigma$ ), and coefficient of variability (c.v.) for bunch and plant characteristics of five high yielding plantain clones tested in six ecological regions of Puerto Rico

\begin{tabular}{lccccccc}
\hline \multirow{2}{*}{ Characteristic } & \multicolumn{2}{c}{ Range } & & \multicolumn{3}{c}{ Values for } \\
\cline { 7 - 8 } & Min. & Max. & & $\bar{X}$ & & $\sigma$ & C.V. (\%) \\
\hline Bunch weight $(\mathrm{kg})$ & 7.1 & 21.1 & & 13.1 & 2.50 & 19.0 \\
Number of hands/bunch & 3 & 8 & & 6.8 & .71 & 10.6 \\
Number of fruits/bunch & 24 & 60 & & 44 & 5.89 & 13.4 \\
Diameter of pseudostem $(\mathrm{cm})$ & 11.4 & 21.8 & & 17.3 & 1.98 & 11.5 \\
Plant height $(\mathrm{m})$ & 2.3 & 5.9 & & 3.7 & .51 & 13.8 \\
\hline
\end{tabular}

future Pn generations (number of asexual generations from a single parent $)^{4}$.

Neither of these two plantain types are of economic importance in the local market. Perhaps the "Hartón", a local horn-type plantain producing bunches with fewer than 5 hands and less than 30 large fruits originated as a somatic mutation from the Maricongo.

The appearance of the French-type plantain in clonal propagations of the horn-type Maricongo cultivar, which continued to produce "true-totype" offspring may indicate that selection based on obtaining a large number of fruit/bunch from the latter cultivar may result in sharp increases in the proportions of French type plantain of inferior market value in Puerto Rico. This condition was also observed in a plantain population originating from Maricongo multiplied by tissue culture techniques, and has been reported elsewhere (9). In both cases, about $27 \%$ of the plant population had French type characteristics in the $\mathrm{P}_{1}$ generation.

${ }^{4}$ Author's unpublished data. 

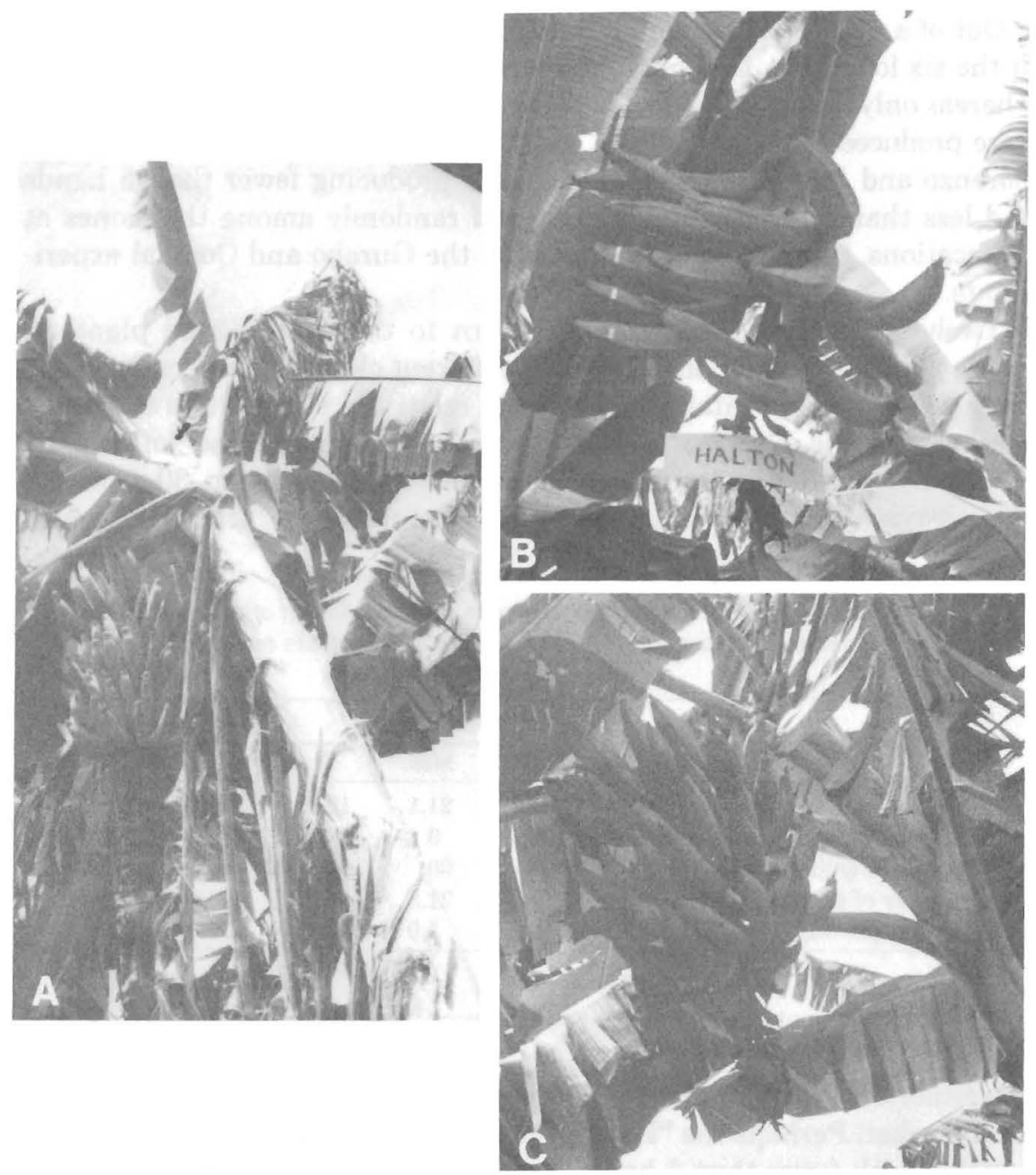

Plate I. Bunch phenotypes obtained from a clonal selection of a Maricongo plantain cultivar. A- French or Congo plantain; B- Hartón; C- Maricongo.

The origin and perpetuation of both non-mutant (reversion) and mutant plants from the Maricongo plantain may be explained by the behavior of chimeras. Considering that all horn-type plantains arose from a common ancestor, the French plantain (12), it might be speculated that the Maricongo cultivar is being propagated as a sectorial or mericlinal chimera. Since this chimera is unstable, depending on the sector of the corm from which the buds or suckers originate, this mutation is capable of giving rise to at least three kinds of tissues, and consequently to different phenotypes (Plate I). Plants originating from the nonmutant 
tissue will resemble the parental ancestor, those arising from the wholly mutant sector will evidence a new phenotype and those derived from the mixed tissue will continue to resemble the parental, unstable phenotype. These unstable individuals are represented in a Maricongo population by those plants bearing horn-type bunches containing 30 to 60 marketable fruits. Perhaps the proportion of non-mutant and mutant tissues in the propagating corm determines the size and number of fruits/bunch. Other assumptions described in the literature (4) that might explain this condition are the amount of tissue derived from L-II and L-III, replacement of one of the tissue layer by another and different levels of ploidy in the layer cells.

Suckers arising from either wholly non-mutant or mutant tissues are fairly stable and produce "true-to-type" plants. The non-mutant individuals are represented in the Maricongo population by those "reverted"

TABLE 3.-Effect of location on bunch and plant characteristics of 12 plantain clones

\begin{tabular}{lcccccc}
\hline & \multicolumn{3}{c}{ Bunch characteristics } & & \multicolumn{2}{c}{ Plant characteristics } \\
\cline { 2 - 3 } & Fruits & Hands & Weight & & $\begin{array}{c}\text { Diameter } \\
\text { of } \\
\text { pseudostem }\end{array}$ & $\begin{array}{c}\text { Plant } \\
\text { height }\end{array}$ \\
\hline Cidra & no. & no. & hg & & $\mathrm{cm}$ & $\mathrm{m}$ \\
San Lorenzo & $45.6^{\mathrm{al}}$ & $6.8^{\mathrm{b}}$ & $13.3^{\mathrm{a}, \mathrm{b}}$ & & $17.3^{\mathrm{b}, \mathrm{c}}$ & $3.5^{\mathrm{d}}$ \\
Rocha & $45.3^{\mathrm{a}}$ & $6.7^{\mathrm{b}}$ & $11.6^{\mathrm{c}}$ & & $16.8^{\mathrm{c}}$ & $3.3^{\mathrm{e}}$ \\
Aguas Buenas & $44.2^{\mathrm{a}, \mathrm{b}}$ & $7.1^{\mathrm{a}}$ & $14.1^{\mathrm{a}}$ & & $17.3^{\mathrm{b}, \mathrm{c}}$ & $3.7^{\mathrm{c}}$ \\
Corozal & $43.0^{\mathrm{b}}$ & $6.6^{\mathrm{b}}$ & $13.0^{\mathrm{b}}$ & & $17.8^{\mathrm{b}}$ & $4.0^{\mathrm{b}}$ \\
Gurabo & $41.1^{\mathrm{c}}$ & $6.4^{\mathrm{c}}$ & $13.6^{\mathrm{a}, \mathrm{b}}$ & & $19.3^{\mathrm{a}}$ & $4.5^{\mathrm{a}}$ \\
\hline
\end{tabular}

${ }^{1}$ Means followed by the same letters do not differ significantly at the $\mathrm{P}=0.05$ probability level.

plants bearing French-type bunches, whereas mutants are represented by those plants producing horn-type bunches with fewer than 5 hands and less than 30 large fruits.

The frequency of reversion in the Horn-Maricongo toward the Frenchtype plantain is calculated at $0.2 \%$, whereas the permanent change to typical "Harton" with less than 30 fruits/bunch is 2 to $3 \%$ for all clones at all locations.

There were no clone $\times$ location interactions for any of the bunch and plant characteristics studied. However, growth and yields of the clones were markedly affected by the prevailing ecological conditins at the various locations (table 3). Highest number of fruit/bunch, an average of 45, were obtained at Cidra, San Lorenzo an Rocha. Except for Rocha, this production was significantly superior to that at Aguas Buenas, Corozal and Gurabo. 
The heaviest bunches, with an average of $14.1 \mathrm{~kg}$, were obtained at Rocha. Bunch weight differences from Corozal, Cidra and Aguas Buenas were not appreciable, but the fruits produced at Rocha were significantly heavier than those from San Lorenzo and Gurabo.

Plantains at Corozal had the thickest pseudostems and attained the greatest height: $19.3 \mathrm{~cm}, 4.5 \mathrm{~m}$, respectively. Plants at Gurabo were shorter and yielded the smallest bunches in terms of number of fruits and hands, as well as weight. The lower production at this location may be attributed to the heavy soil with restricted interior drainage resulting in a poorly developed root system (7), and less plant growth and yields. Results from previous experiments using similar clonal material showed that yields were about 20\% lower at Gurabo than at Corozal (8).

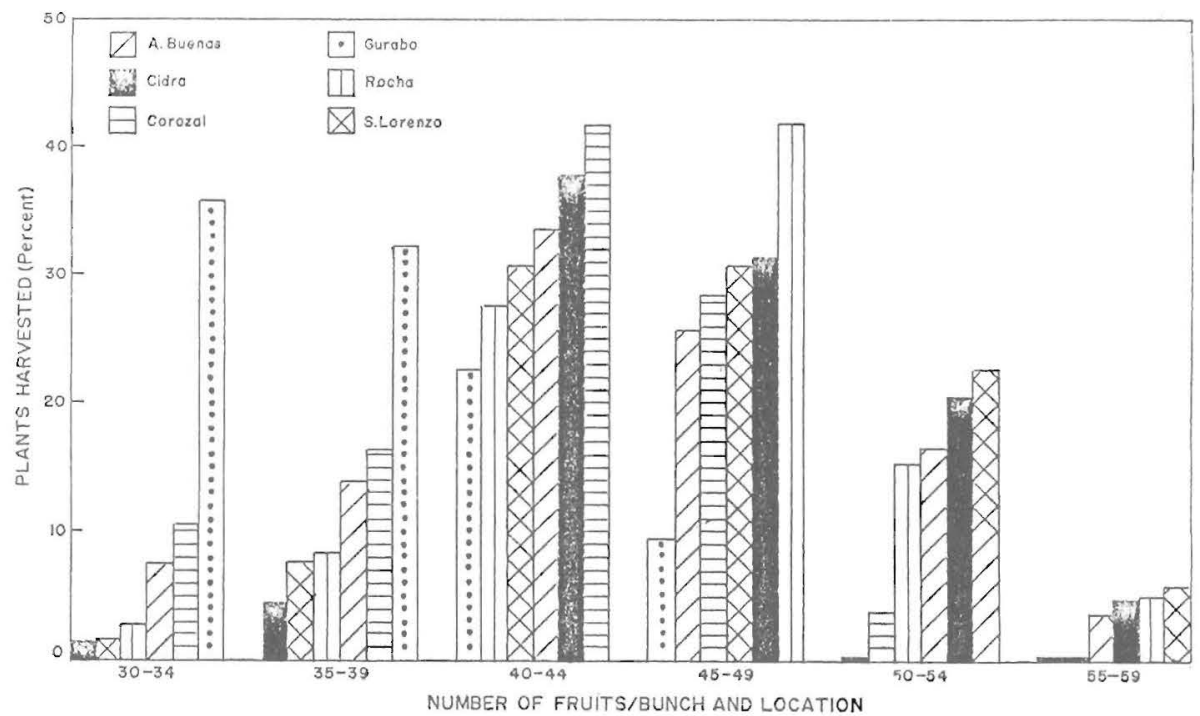

FIG. 3.-Grouping of plants harvested from five plantain clones at six locations on the basis of number of marketable fruits/bunch.

The 613 plants harvested from the five superior clonotype populations were arranged into six groups on the basis of number of fruits/bunch produced at each location (fig. 3). Plants producing fewer than 30 fruits/ bunch were included in the 30 to 34 group, whereas those yielding 60 horn-type fruits were added to the 55 to 59 group. Plants bearing Frenchtype bunches were not included.

The greatest number of plants yielding 40 to 49 fruit/bunch were recorded at Corozal, about $69.7 \%$. This was offset by $26.8 \%$ of the plants which produced less than 40 fruits/bunch at this location. The largest number of plants producing less than 40 fruits/bunch were found at Gurabo, 68.0\%. 
An average of $23.1 \%$ of the plantains harvested at San Lorenzo, Cidra, Rocha and Aguas Buenas yielded 50 or more marketable fruits/bunches. At Corozal only $3.5 \%$ of the plants produced bunches with 50 or more fruits and at Gurabo none of the plants produced more than 45 to 49 fruits/bunch.

Figure 4-A shows the distribution for 613 plants harvested at all

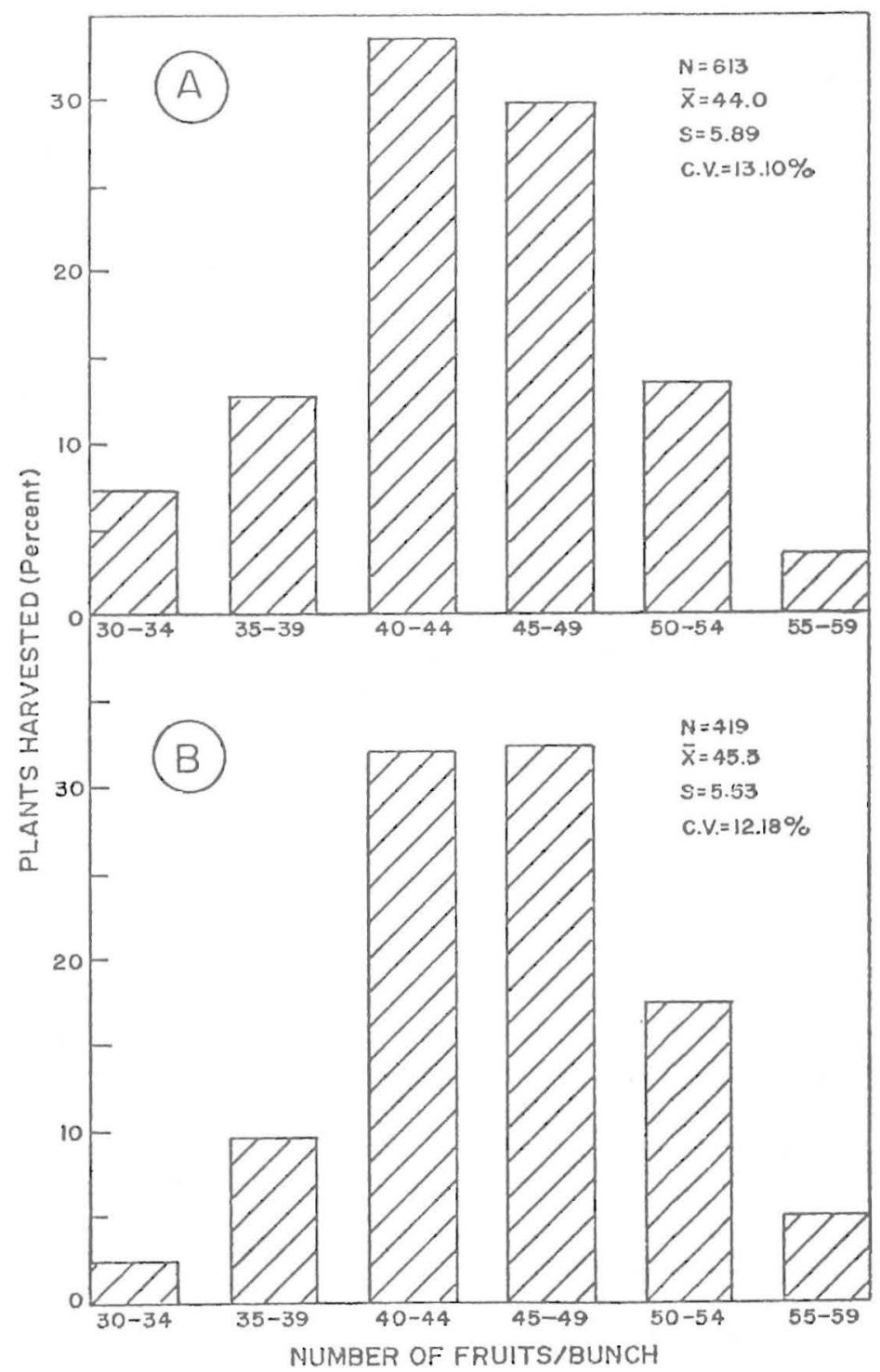

FIG. 4.-Frequency of bunch distribution of 5 plantain clones harvested at six (A) and four (B) locations in Puerto Rico. 
locations into six groups on the basis of number of marketable fruits/ bunch. With a mean production of 44 fruits/bunch and an $\sigma$ value of 5.89 , it is estimated that about $77.0 \%$ of the plants will yield bunches with 38 to 50 fruits. Considering plants producing above and below these limits, it is predicted that $11.1 \%$ of the plantain selections will yield bunches with more than 50 fruits, thus increasing to about $88.1 \%$ the proportion of this population producing 38 or more fruits/bunch. The remaining plants, about $11.9 \%$, will produce less than 38 fruits/bunch.

If the data for Corozal and Gurabo, where number of fruits/bunch as much lower is discarded (table 3 ), the mean bunch production would be increased to 45.5 fruits with an $\sigma$ value of 5.53 (fig. 4-B). Using these values it is estimated that about $74.5 \%$ of the clonal population would yield bunches with 40 to 51 fruits at Cidra, San Lorenzo, Rocha and Aguas Buenas. Considering that $12.9 \%$ of the plants produced bunches with more than 51 fruits, it is predicted that about $87.4 \%$ of the plants have the potential for producing 40 or more fruits/bunch at these four locations. Plants producing bunches with fewer than 40 fruits comprise about $12.6 \%$ of the clonal population.

To obtain a Maricongo clonal selection averaging about 45 marketable fruits/bunch in the plant crop a farmer must always establish new plantain fields with propagation material directly derived from paternal plants capable of yielding 50 or more fruits. To maintain the high yield potential of the clonotype, none of the plants producing less than 40 fruits/bunch should be used in future plantings. It is from the lower limits of this group of plants that low yielding undesirable "true-to-type" individuals arise. These plants, as well as other "off-types" and undesirable individuals, must be marked and rogued out. If these plants continue to mingle in the population, their "true-to-type" behaviour will cause them to increase in relative number and the high yield potential of the selection will be lost after Pn generations.

\section{RESUMEN}

Cincuenta y siete selecciones clonales del plátano Maricongo se evaluaron en seis zonas ecológicas de Puerto Rico. Cinco de éstas eran parecidas en rasgos morfológicos y consistentemente clasificaron entre las de mejor rendimiento en todas las localidades a base del número de manos, número de frutas y peso del racimo.

Estas selecciones produjeron una media de 44 frutas comerciales por racimo que pesaron $13.1 \mathrm{~kg}$. Aunque el método de propagación es asexual, la variabilidad entre individuos de una misma población clonal fue alto. El peso de los racimos varió de 7.1 a $21.1 \mathrm{~kg}$ y el número de frutas comerciales de 24 a 60 . 
Algunas plantas demostraron reversión o cambio de la característica del racimo normal o tipo cuerno hacia uno tipo congo. Estos racimos tenían de 64 a 106 frutas pequeñas. Otras plantas produjeron racimos tipo cuerno con menos de 30 frutas grandes (Hartón). Estas plantas aparecieron al azar en todos los experimentos y, a base a su comportamiento probado en otros ensayos, son los únicos que se mantienen fiel al tipo en selecciones clonales de la cultivar Maricongo. Una explicación del posible mecanismo envuelto en este comportamiento se discute en el texto.

Independientemente de la selección clonal, todas las características estudiadas en el racimo y la planta fueron afectadas por las condiciones ecológicas de cada zona. Las plantas cosechadas en los experimentos de Cidra, San Lorenzo y Rocha produjeron los racimos con mayor número de frutas comerciales. Los racimos más pesados se obtuvieron en los experimentos de Rocha y Corozal. Por el contrario, los racimos inferiores en términos de número de frutas y peso se cosecharon en Gurabo.

Considerando la variabilidad en cada población clonal y el efecto de la zona ecológica se puede estimar que de los hijuelos provenientes de una selección de Maricongo con potencial de producir 50 ó más frutas comerciales por racimo, alrededor de un 85 por ciento producirán racimos con 40 ó más frutas en la cosecha de plantilla. Las plantas de porte distinto que producen un número limitado de frutas por racimo deben marcarse y eliminarse. Si estas plantas no se eliminan, por su habilidad de multiplicarse fiel al tipo, al cabo de varias generaciones constituirán una mayoria dentro de lo que una vez fue una selección clonal con un alto potencial de rendimiento.

\section{LITERATURE CITED}

1. Barker, W. G. and F. C. Steward., 1962. Growth and development of the banana plant. I. The growing regions of the vegetative shoot, Ann. Bot. 26 (1003): 389-411.

2. Cheesman, E. E., 1933. Mutant types of the dwarf banana, Trop. Agric. (Trinidad) 10 (8): $4-5$.

3. Chew, V., 1930. Testing differences among means: Correct interpretation and some alternatives, Hortic. Sci. 15 (4): 467-70.

4. Dermen, H., 1948. Chimeral apple sports and their propagation through adventitious buds, J. Hered. 39: 235-42.

5. Esau, K., 1960. Anatomy of seed plants, John Wiley and Sons, Inc.

6. Gross, R. A. and N. W. Simmonds, 1954. Mutations in the Cavendish banana group, Trop. Agric. (Trinidad) 31: 131-32.

7. Irizarry, H., J. Vicente-Chandler, and S. Silva, 1981. Root distribution of plantains growing on five soil types, J. Agric. Univ. P.R. 65 (1): 29-34.

8. — J. Rodriguez-Garcia, and N. Díaz, 1981. Effect of three population densities and fertilizer levels on yields of high yielding clones of plantains at two locations, $J$. Agric. Univ. P.R. 65 (4): 395-400.

9. Ramcharan, C. and W. I. Kanausenberger, 1983. A preliminry evaluation of field- 
420 JOURNAL OF AGRICULTURE OF UNIVERSITY OF PUERTO RICO

planted Maricongo plantains grown from explants, Proc. Caribbean Food Crops Society, XIX Annual Meeting, Mayagüez, P.R.

10. Richardson, D. L., 1961. Note on the reversion of the dwarf banana "Cocos" to "GrosMichel", Trop. Agric. (Trinidad) 38: 35-7.

11. Schamel, A. D. and C. S. Pomeroy, 1936. Bud mutations in horticultural crops, J. Hered. 27: 487-94.

12. Simmonds, N. W., 1955. Taxonomy and origins of the cultivated banana, J. Linn. Bot. Soc. $55: 302-12$. 